\title{
Cartel Politics Model in Single Candidate Election in Tasikmalaya Regency
}

\author{
Edi Kusmayadi ${ }^{1}$, Akhmad Satori $^{2}$, Subhan Agung ${ }^{3}$ \\ \{edi kusmayadi@unsil.ac.id ${ }^{1}$, akhmadsatori@unsil.ac.id ${ }^{2}$, subhanagung@unsil.ac.id ${ }^{3}$ \} \\ Siliwangi State University, Indonesia ${ }^{1}$ \\ Siliwangi State University, Indonesia ${ }^{2}$ \\ Siliwangi State University, Indonesia ${ }^{3}$
}

\begin{abstract}
This study aims to find out how political cartelization and the emergence of a single candidate phenomenon in simultaneous post-conflict local elections in Tasikmalaya District in 2015. Descriptive qualitative research methods used in this study, with normativism political science study approach, analytical techniques using interactive methods and data explored in depth through knowledge informant. The results of the study show that the Pemilukada of a single candidate is full of engineering by local and national political actors so that there is only a single candidate. Political elites control other powers, and the influence of incumbent forces that are too large "closes" other political forces to compete. Failure of other powers, because of the immaturity of strategies and considerations before the appearance of the Constitutional Court's ruling on the Single Candidate Election.
\end{abstract}

Keywords: Local Election, Single Candidate, Cartelization, Regulation.

\section{Introduction}

The direct election of Regional Heads simultaneously has undergone a new phase. The new round was marked by the success of the first wave of Direct Election by the General Election Commission (KPU) and just February and April 2017, the General Election has been held in the second wave simultaneously. If you look at the event, you can be sure the General Election Commission (KPU) can hold the event successfully, safely and without excess.

Law No. 1 of 2015 concerning the stipulation of Perpu No. 1 of 2014 concerning the election of Governors, Regents and Mayors into Laws as updated by Law No. 8 of 2015 concerning the Election of Governors, Regents and Mayors, carried out simultaneously in the first phase of Indonesia. The elections took place on December 9, 2015 and later in 2017. However, on the way the Law No. 1 of 2015 in conjunction with Law No. 8 of 2015 this has created new problems, namely the existence of a single candidate in several regions in Indonesia, one of which is Tasikmalaya Regency, although the registration of Regent Candidates has been extended to two extensions by the Tasikmalaya Regency Election Commission, but did not add a partner Regent candidate. The chaos of a single candidate occurs because the election law does not clearly regulate the registration mechanism if there is a single candidate. Political parties are increasingly pragmatic by not nominating their 
cadres for various reasons. The administrators of political parties in the regions are shocked and stutter so they cannot compete with the incumbent. The political dynamics that occurred at that time revealed that the Tasikmalaya District Election had to be postponed to 2017, because there was only one pair of prospective candidates who came. For this backgrond, question of the research is "How political cartelization can be formed in a coalition of political parties so as to bring up a single candidate?".

\section{Literature Review}

\subsection{Direct Democracy}

The process of direct democracy through Pilkada is a penetration of the great traditions that will be carried out in the local community. In its implementation, the implementation of the direct regional head election system has led to a dualistic view between those who are pessimistic and optimistic [1]. Fundamental reasons that can be raised in addressing the shift in the format of local politics, namely academic reasons and practical reasons. Academically the development of the latest political science including political studies in Indonesia shows the debate about the concept of democracy that takes place dichotomically between Schumpeterian democracy and its critics [2].

Schumpeterian advocates of democracy formulate democracy as an institutional procedure to reach decisions where individuals get the power to decide through competitive battles to get the votes of the people. These democratic principles are not only strongly believed in the academic world, but have become the main reference in the practice of politics and government in Indonesia [2]. Schumpeterian's democratic approach which only emphasizes the electoral dimension and representative institutions raises objections from various circles. According to Teri Karl, in addition to the electoral dimension, it is necessary to take seriously the non-electoral dimensions such as civil liberties. For liberals, democracy provides a guarantee of freedom that is unmatched by any political system [2].

\subsection{Political Concept of Cartel}

Cartel is a new term in the realm of Indonesian politics. The cartel is a tendency for the behavior of political elites who are in power to preserve power through covert means. In an effort to perpetuate power, individuals have a very dominant role.

The purpose of the cartel is actually to prepare strategic steps and build a pseudooligarchic framework so that the order of political parties does not shift away from their elite subjective interests. The social impacts caused by this kind of cartelization include: weakening of the control system from within the political parties, weak regeneration and strengthening of authoritarian attitudes, easy collusion, corruption and nepotism, political elites losing the orientation (disorientation) of state and society, the widening of social inequalities and politics between the elite and the people and ultimately weaken the political participation of the people so that the nation's political development does not work.

According to Ambardi [3] in his paper, the concept of cartel was first introduced by Daniel Katz and Peter Mair in 1995, where at that time new parties with different types of 
patterns emerged which were later called the cartel party. The previous party was more of a cadre party, a mass party and a cross-group party. Eva Kusuma Sundari also mentioned the same thing about the characteristics of political cartels, namely: first, the disappearance of the role of party ideology as a determinant of inter-party coalitions. Second, permissive attitude in coalition formation. Third, there is no opposition that really criticizes the government. Fourth, elections have no effect in determining party behavior. Fifth, the strong tendency of the party to act collectively as a group. In Indonesia the strengthening of cartel politics occurred in the post-reform era.

Meanwhile Daniel Dhakidae has a different emphasis on discussing this political cartel. According to him, "cartel" is a very formal term and is known in economic concepts. The cartel aims to control something for example the purpose of controlling prices. Cartels only live in capitalist society. There has been a transmutation of the term cartel from an economic concept to a political concept. Actually, oligarchy is the origin of cartels in the concept of politics. There was a big mistake that occurred in the post-1998 process in which changes in the improvement of democracy towards electoral were more highlighted than clearing up all state institutions. That's where the gap allows oligarchy to grow and form a very strong network so that if there is no drastic change there will be no change. Political parties in Indonesia form an inner circle that controls assets and information so that people in the outer circle cannot penetrate and know what is happening in the inner circle. On the one hand Indonesia wants to grow into a liberal democracy, but on the other hand it does not have the equipment in the form of an adequate control mechanism.

\subsection{Political Communication and the Quality of Simultaneous Election}

According to McCormic et al [4] there are 5 aspects that become famous models in the communication process, namely: sender (message giver), channel (channel, media), message (message delivered), receiver (recipient of the message), and impact (the impact of the message). This model is a conventional model that is also commonly used in the process of political communication. For example in the context of Pemilukada that is a sender are political elites, mass media and others, the message is in the form of certain political issues or their image, the media channel, usually depends a lot on effectiveness and creativity, the receiver is society and impact is certain political opinions or actions. In this model the role does not have to be as above, a role can change depending on its potential and political arena. Pemilukada can be said as a political arena in which there is information exchange between political elites as senders.

According to Chalik [5] in the Reformation Era, local politics was controlled by three groups. First, bureaucrats who have a background in nobility who have managed to survive through various regimes since the colonial period. Second, bureaucrats who come from ordinary people. Third, strongmen local. There are times when all three operate separately, but there are times when allied. Depends on interests. In local strongmen one of them is the religious elite operating in the political sphere. In Indonesian history, religious elites have a vital role as other political elites.

\section{Research Methods}


The research method used is qualitative research methods. Technically qualitative research method is a research procedure that produces descriptive data such as speech or writing and behavior that can be observed from people who are the subject of research. This approach directly points to the settings and individuals in the setting as a whole, the subject of the study in the form of groups, organizations or individuals themselves. This will not be narrowed down to separate variables or hypotheses but be viewed as a whole. Analysis of the data in this study uses an interactive analysis of Mathew B Miles and Michael Huberman. That is when the data collection process the researcher keeps moving between: data reduction (selection or simplification of data), data presentation and drawing conclusions / verification. The three components, the activity in the form of a relational relationship as a cycle. That is, after the data collection ends, researchers begin to move regularly to data reduction, then data presentation and conclusion drawing.

\section{Result and Discussion}

Whereas all stages of post-conflict local election all went smoothly, but when entering the nomination stage, the KPU of Tasikmalaya Regency only got one candidate pair, namely Uu Ruzhanul'Ulum and Ade Sugianto, as incumbent couples. Registration is then extended to 3 consecutive times in three different registration periods. The result is that there is still only one candidate pair. So according to PKPU, the KPU of Tasikmalaya Regency then postponed all stages of the General Election. The next latest political development is the emergence of Constitutional Court Decision Number: 100 / PUU-XIII / 2015 dated September 29, 2015 regarding 1 (one) candidate pair in the simultaneous 2015 election of Regional Head and Deputy Regional Head, where the core is Regency / City which only having one candidate pair can continue the stage of Pemilukada and can be held in 2015 by asking the community to agree or disagree with the single candidate pair. If most people approve the single pair, then the pair will be appointed as the winner of the General Election, but if the opposite does not agree more, then the Pemilukada will be postponed in the next Pemilukada next, namely 2017. It was through the Constitutional Court's decision that the Indonesian KPU ordered the three districts with one candidate pair, namely Tasikmalaya Regency, North Tengan East Regency, East Nusa Tenggara and Blitar Regency KPU, East Java through Circular No.644 / X / 2015 to revoke the decree about delaying the stages of the election and creating a new stage with the time for the voting to be held on December 9 , 2015 .

The emergence of a single candidate in simultaneous Pemilukada in Tasikmalaya Regency is inseparable from the map of political power that emerges in the political dynamics before the General Election, the win-lose count and the profit of each party politics is clearly very obvious during the nomination process. The political party in Tasikmalaya seems surprised by the event. At the beginning of the stage there were no signs of a coalition being formed. Some political parties have joined in building coalitions. Four parties namely Gerindra, Democrat, PAN and PKS have formed the Sukapura Pearl Coalition (KMS) since November 2014. Chairman of the Democrat Party DPC of Tasikmalaya Regency, Ucu Asep Dani admitted that there had been an agreement between four political parties joined in KMS. But until now there has been no name for the candidate for the regent and vice-regent 
candidate to be promoted [6]. The Coalition was confirmed by the declaration at Cipanas Galunggung, Thursday, March 26, 2015. Two days later, on Saturday, March 28, 2015, the PDI Perjuangan sought the Golkar Party to move forward together to join hands towards the election. However, at the time other political parties had made out, the United Development Party (PPP) and the National Awakening Party (PKB) were still over. In fact, the PPP and PKB have great power in the legislature.

Ahead of the registration stage of prospective candidates, the constellation is increasingly dynamic. Each political party looks for ways to secure themselves. The coalition must bear "victory". As a result, the intimacy of KMS did not last long. Coalition broke. PAN and PKS chose to leave the KMS. They chose to unite with the PDI-P and Golkar to bring Uu Ruzhanul Ulum-Ade Sugianto as the candidate for the Tasikmalaya regent and vice regent. That is the only pair whose requirements are accepted and approved by the KPU of Tasikmalaya Regency. Only four political parties are left: PPP, PKB, Gerindra, and Democrats. Gerindra and Democrats finally carry out Ruhimat-Nandang Gaosul Adim (Naga). But finally, the pair ran aground at the end of the registration time. Ruhimat resigned from the nomination exchange. The dragon cannot advance alone. Until the registration round ends. PPP internal conflict which causes the central management to be divided into two. The stretcher is divided. KPU cannot accept that. Does not meet the rules. Tasikmalaya District Election ends anticlimax. There is only one prospective candidate for regent-vice regent. The elections which are planned to be held on December 92015 are in the delays. Then the KMS consists of Democrats six seats, PAN six, Gerindra four, and PKS two seats. It has exceeded the 20 percent requirement [7].

The outbreak of the Koalisi Mutiara Sukapura (KMS), originated from the maneuvers carried out by the Ruzhanul Ulum Law which approached parties outside the United Development Party (PPP). This was triggered by the existence of internal conflicts at the central level that occurred in the body of this party which required carrying the same candidates in the General Election. But as we know Uu Ruzhanul Ulum is only promoted by the PPP's Romahurmuzy camp. While the PPP version of Dzan Faridz is more inclined to bring H. Ruhimat as Chairman of the United Development Party DPC (PPP) version of Djan Faridz. This condition makes Uu Ruzhanul Ulum then approach figures from the National Awakening Party (PKB). Uu Ruzhanul Ulum tried to get close to another party that was eligible in the nomination besides PPP, due to internal dynamics in the PPP at the central level which made it impossible for him to leave using the party's "boat" bearing the Ka'bah symbol. Uu Ruzhanul Ulum then approached the PKB to carry it as a regent candidate. The next political development was that $\mathrm{Uu}$ approached PKB with the hope that PKB was nominating H. By Soleh PKB cadre. But at the lower level the PKB wanted Haris Sanjaya to become the vice regent candidate. Uu Ruzhanul Ulum's political maneuver tried to approach other parties such as Ade Sugianto (incumbent vice regent). Even the PDI Perjuangan issued a DPP Decree which gave a mandate to Uu Ruzhanul Ulum and Ade Sugianto to become candidates for the 2016-2021 Regent and Deputy Regent.

The political map became even warmer because it turned out that Uu Ruzhanul Ulum at the end of the registration period on 30 July 2015 preferred Ade Sugianto as his candidate for vice-regent. The pair was initially carried by 4 parties, namely the 6-seat National Mandate Party (PAN), the 2-seat Prosperous Justice Party DPRD, 7-seat PDI-Perjuangan. The emergence of a single candidate in Tasikmalaya can also be caused by a political force that indirectly conditions the emergence of a single candidate, with KPU regulations on 
Nomination, until later in October 2015 the KPU resumed the stage based on the Judicial Review Judicial Review decision on Election with a single Candidate Pair can be continued on 9 December 2015, by asking the voters to agree or disagree with the single candidate pair. The emergence of a single candidate is due to the too dominant political power that carries the incumbent pair so that other forces are locked. Incumbent managed to gather strength from one side, but from the other side the incumben was "imprisoned" with such great support but was unable to create an "opponent" so that the General Election in accordance with the regulations was postponed, then the Local Election appeared with one candidate pair.

The phenomenon that arose later was what was said by Ware and Wolinets political party scientists in Erawan [8] as a cartel party, where the ruling party or ruling elite was high in using State resources and acting as a force that other forces could not resist. Other parties even "came close" looking safe to unite with the ruling party or supporters of the ruler. In this model it is very difficult for the emergence of the same strong contestation, because other forces have been taken away, even if rival rulers emerge, it is only the power of the rulers or puppets. This happens because the forces of political parties and elites are only dependent on the target of political position (target on political position).

Cartel politics relies on political position not on victory Election is because according to the elite the victory in elections or election is not important, because what is important is being able to approach election winners who "lick it" to be given a good political position. Therefore, the political conditions of the cartel will always appear political deals with the winner of the contestation. Whereas the others become bearers, supporters in the hope of getting a position or profit from the victory. Even though they were originally rivalling, they will the point is to "embrace" the winner in order to gain political advantage, in the form of a strategic political position.

In the case of the 2015 Tasikmalaya District Election, political communication took place in two vortexes of great power. First, political communication between political forces that are close to the incumbent camp. This political power is very large and even because of the size of this camp it fails to make enemies, because most of them are close to the incumbent. Although it seems not solid, but the proof of this power is inhabited by party political elites more than the other camp, and some are also impressed "looking safe". This group is represented by the Ruzhanul Ulum Act and Ade Sugianto faction with the strength of the PPP party Romy (non-bearers), Golkar (non-bearers), PDI-Perjuangan, PAN and PKS. Second, the strength of $\mathrm{H}$. Ruhimat who was strongly supported by Gerindra (the bearer) built political communication with several elements of community power, the PPP stronghold of Dzan Farid also mobilized more power in the community and was supported by community leaders and charismatic clerics in Tasikmalaya Regency. Both are in accordance with the Pemilukada process to mobilize their respective support and the object of the pressure is the election organizer, both the KPU and the Election Supervisory Committee.

\section{Conclusion}

First, the phenomenon of a single candidate that emerged in Tasikmalaya was caused by a political constellation which locked the contestation of party power battles that existed 
to one of the main powers of the ruling party which tended to carry incumbent pairs, so as not to give other coalitions an opportunity to compete.

Secondly, large political parties are actually "rented" by the incumbent pair so as to suppress the widest possible opportunity for other parties to bring other partners to contest.

Third, the cartelization model arises because of the efforts of each political party that has relatively weak resources to take maximum advantage even though by pawning the ideology and policies of its party institutions by "docked" to the greatest power that appears in accordance with the political constellation.

\section{References}

[1] A. A. O. Mahendra, Pilkada di tengah konflik horizontal: Nurmahmudi Ismail unggul di KPUD, Badrul Kamal menang di Pengadilan Tinggi. Dyatama Milenia, 2005.

[2] A. A. Dwipayana, Bangsawan dan kuasa: kembalinya para ningrat di dua kota. Institute for Research and Empowerment, 2004.

[3] K. Ambardi, Mengungkap politik kartel. Kepustakaan Populer Gramedia, 2009.

[4] J. McCormick, "Government and Politics: Political Communications," London Red Globe Press, 2019.

[5] A. Chalik, Pertarungan elite dalam politik lokal. Pustaka Pelajar, 2017.

[6] Kabar Priangan, "23 February 2015 Edition," Kabar Priangan. .

[7] Pikiran Rakyat Online, "March 26, 2016," Pikiran Rakyat Online. .

[8] I. K. P. Erawan, Bahan Perkuliahan Teori Partai Politik dan Sistem Pemilu. Pascasarajana Ilmu Politik UGM, Yogyakarta., 2011. 